\title{
Pacific Coast States
}

National Cancer Institute

\section{Source}

National Cancer Institute. Pacific Coast States. NCI Thesaurus. Code C43455.

The area in the United States comprised of the following states: Alaska, Washington,

Oregon, California and Hawaii. 